\title{
Can the social market economy be a viable solution for a future sustainable development of the Romanian economy? -Quantitative evidence-
}

\author{
Vasile Alecsandru STRAT \\ The Bucharest University of economic Studies, Bucharest, Romania \\ vasile.strat@csie.ase.ro \\ Cristian ȘTEFAN \\ Bucharest, Romania
}

\begin{abstract}
Social market economy (SME) is a socio-economic model which attempts to unite the freedom of a competitive market economy with social equilibrium and progress. It is seen as a "third path" besides a purely liberal market economy and an economy which is heavily regulated by the state - in the SME there is an intermediate degree of regulation. Historically, the model corresponds to the real economic policy of the German Federal Republic after the 1950s, thus it is sometimes called Rhine capitalism. According to the Treaty of Lisbon from 2007, the European Union pursues a competitive social market economy with full employment and social progress. On one hand, this model wishes to exploit the advantages of a free market economy, especially its high efficiency in the production of goods, while on the other hand it uses state intervention to correct for potential negative outcomes from market processes. Further characteristics of this model are: ensuring competition, free price formation, private property, motivating performance through profit aspirations as well as guarding personal freedoms. Last but not least, this model encompasses a strong structural policy by encouraging weaker geographical regions or industries. Therefore, it is highly probable that such a socio-economic model might be the appropriate alternative to fuel a sustainable growth of the Romanian economy. Using county level data, from the National Institute of Statistics and from the National Office of the Trade Register, for the year 2015 we show that the Romanian economy is highly polarized with a few growth poles (islands) and a large number of underdeveloped units. Thus, it becomes obvious that these important disparities will hinder a future sustainable development and by consequence a clear "road-map" represented by this economic model might prove to be a viable solution for the Romanian economy.
\end{abstract}

Keywords: Social market economy, regional development, regional disparities, economic development trends

\section{Introduction}

The implementation of the real social market economy, as envisaged by Muller Armak, and implemented in Germany and some northern European economies, might be the answer to most of the problems occurred during the last years, both at the level of the European Union and at the level of the national economies of some member states. Even though it might seem simplistic at first glance, it is possible to observe that most of the negative issues raised at the level of the European Union have a common source which is represented by the existence of severe disparities: between different economies, between different regions, between different socioeconomic groups and ultimately between different citizens. What is also noticeable is that these disparities can be observed both at macrolevel (EU level) and at micro-level (inside a national economy). Therefore, the social market economy, which is mainly trying (and as seen in some economies succeeds) to ensure that 
the right balance is maintained between the economic players, by correcting/eliminating market failures that might arise on the liberal market, looks like being an option that needs further investigation.

In the case of Romania, the necessity of a new and enhanced economic model is obvious in both what the internal affairs and its place in the European Union are regarded. The socio-economic model of market economy that has been constructed on the wreckages of the former communist over regulated and centralized model has clearly reached its limits and has failed to position the country on a path of sustainable development. The severe disparities created among regions and among socioeconomic classes are the most important causes of the Romanian immigration waves and of the generally lagging economy, in the broader European context.

In order to provide some clear evidences of the severe regional level disparities we use data on four main economic indicators (at county level) and visually present their distribution at the level of the country, using maps and histograms.

The paper includes a section where the general framework and a brief review of the literature is presented, a short section where the methodological approach is described and a section where the main findings are presented. These sections are accompanied by some introductory and conclusive remarks.

\section{General framework and literature review}

The social Market economy (social capitalism or Rhine capitalism, as presented by some authors, Bakan and MacDonald, 2002) is one of the three important socioeconomic models present in the nowadays world. It is structured and described both by scholars and practitioners as an "optimal" mix between the free market capitalism of the right side and the social economy of the left side, being an economic model (Goldschmidt and Rauchenschwandtner, 2007) which is successfully applied in the German economy (Spicka, 2007) and also some north European Economies (Turner, 1998).

On one hand, this model allows the economic development of the free market, but on the other hand it tries to provide "fair/equal" opportunity to all economic participants, through its social side (Wheeler, 2002). Under any circumstances, the model, which is clearly designed not as the third way, but as the middle way, tries to impose the strict economic and social boundaries specific to the socialist, over-regulated and centralized economies. By using all the economic, monetary, fiscal and social instruments available, the social market economy struggles to ensure the general welfare and as a consequence to diminish all disparities which might lead to both social and economic disequilibria between the actors of the economic game.

As envisaged by Muller-Armack (1956) and Eucken (1932), the social market economy brings the balance between the free enterprise and the social responsible program as mandatory condition for the economic performance. Thus, the regulatory quality promoted by the state's authority plays a significant role in the day to day implementation and success of this "middle" economic model. As consequence, as several authors have argued (Scharpf and Fritz, 2009) and as F.A. Hayek has "predicted" in 1939, the latest evolutions of the European Union (as it is designed today) do not seem to be supporting the development of the social market economy, due to the fact that they promote the "weakening" of the national authorities which are in the case of SME the main catalyst and balance keeper. More exactly, in the nowadays framework of the European 
Union, the common market and the migratory flows seem to be the most important elements destabilizing the European social market economies, by putting pressure on the social side of the model. However, it does not need to be forgotten that the early stages of the EU when the national governs kept their control over the economic integration, the European social market economies were reaching the peak of their development, and the EU was considered then an enhancer of this economic model. On the same time, the nowadays EU with its large common market is a catalyst for the economic development of these strong economies and therefore, maintaining the balance between the two important elements of this economic model seems to be the most important challenge for the social market economy, emerged from the new developments of the broader European socioeconomic context.

As some stakeholders propose, the long term solution for the social market economy, which is represented by the creation of the European level institution, in a "federal Europe" (Buchanan, 1995/96 ) that can ensure the balance at Union level does not seem a realistic framework in the present conditions when consensus among members is more like a "rara avis". On the contrary, the "defensive" solution which proposes the preserving and in some cases even the restoration of the national level powers seems to be the more realistic situation, hindering in this way the entire integration process (solution which also emerges from the white paper presented by the President of the Commission, on the $1^{\text {st }}$ of March 2017). Thus, taking in consideration the advantages brought by such a socio-economic system, and also its limitations, a stepwise solution might be the optimal solution that would ensure the survival and the development of this socio-economic model. More exactly, a broader European model would be feasible only when it would be constructed by merging several smaller social market economies. Therefore, the next natural step should be represented by the development of such social market economies in as many as possible EU member states. In order to increase the feasibility of the model it needs to become more flexible and to reorganize its entire philosophy around the idea of "equilibrium" and reduction of disparities, because this is the most important challenge faced todays by individual EU economies and also by the entire Union. Another remarkable advantage of this stepwise approach would be represented by the emergence of a natural incentive for the diminishing of the east-west and south-north migratory flows, which at this moment increase the socio-economic disparities at the level of the Union, by concentrating the human capital and the labor resource in areas where they also increase the pressure on the social welfare systems, increasing the social turmoil. In the same time, these "uncontrollable" flows of human capital and labor force work against the main regional policies developed by the EU with the clear purpose of reducing the regional disparities.

As far as Romania is concerned, the economic model that was developed after the fall of communism is a market economy which generated important disparities (Goschin et al., 2008) at county level and even regional level. Also by failing to ensure the development of the transport infrastructure which generates a low internal mobility of the labor force and a low attractiveness (for both Romanian and foreign capital) of some regions, the widening of these internal disparities seems to have a large propensity. Another remarkable weak point of the socio-economic development model created in the last 26 years in Romania is represented by the fact that it failed to mitigate fast enough the disparities between the Romanian economy and its western counterparts and generated in this way large migratory 
outflows which have created important disequilibria on the internal labor force market and also on other sectors (social security budgets).

\section{Methodology and data issues}

The research method we adopt in this paper is to analyze four variables, which we consider to be indicative of the level of economic development in the different Romanian counties: i) the number of active firms, ii) the number of employees, iii) the average gross monthly salary in the Romanian currency RON, as well as iv) the degree of urbanization. We start with the assumption that the data on different counties will be quite heterogeneous and we aim to map the regional differences. We collect data from the National Institute of Statistics for the year 2015 and we analyze county-specific data for each variable in that year. Thus, each variable consists of 42 observations, corresponding to the 42 Romanian counties (the city of Bucharest is considered to be a county itself).

We run simple descriptive statistics and chart the distributions of the four variables of interest in order to grasp how the variables behave. Further on, we run Pearson correlations to understand if there is any relationship between the variables. Finally, we design visual data maps which highlight the differences between counties with respect to the variables.

\section{Empirical results \\ Descriptive Statistics}

Table 1 presents descriptive statistics for the variables. It encompasses measures of the distributional center (mean, median), dispersion (standard deviation) and distortion of the normal distribution (skewness, kurtosis).

Table 1. Mean, median, standard deviation, skewness and kurtosis of the four variables in 2015

\begin{tabular}{|l|l|l|l|l|}
\hline & $\begin{array}{l}\text { Number of } \\
\text { Firms }\end{array}$ & $\begin{array}{l}\text { Number of } \\
\text { Employees }\end{array}$ & Salary (RON) & $\begin{array}{l}\text { Degree of } \\
\text { Urbanization }\end{array}$ \\
\hline Mean & 12234 & 109795 & 2235 & 0.4917 \\
\hline Median & 8110 & 79320 & 2133 & 0.46 \\
\hline Std. deviation & 16439 & 125838 & 366 & 0.1374 \\
\hline Skewness & 5.292 & 5.196 & 2.041 & 1.444 \\
\hline Kurtosis & 31.357 & 30.634 & 5.356 & 3.355 \\
\hline No. obs & 42 & 42 & 42 & 42 \\
\hline
\end{tabular}

Source: Authors' own computations, based on data from the National Institute of Statistics, Romania. According to Table 1, the average number of companies active in a county is of 12234. However, the median value is much lower, at 8110, indicating that the level of economic development is highly polarized across counties. The difference between mean and median shows that there are many regions with a low level of economic activity and a few economic strongholds with a very high number of firms. This observation is also corroborated by the relatively high standard deviation compared to the mean, and by the positive skewness and kurtosis of the distribution of number of firms. A distribution with positive skew has a fat tail towards its left side, showing again a large concentration of counties in regions with weaker economic activity. The positive value of kurtosis shows a pointy distribution (compared to the normal distribution), which points out that there is a very large number of under-developed units. 
The most important results from Table 1 are that all four variables follow a similar pattern: what can be observed for the first variable, the number of firms, is valid for the other three variables as well: they all have means higher than the median and positive values for skewness and kurtosis. The result is more striking for the number of firms and number of employees, but it is also valid for salary and degree of urbanization.

All in all, it seems that the Romanian economy is highly polarized, with a few counties yielding the highest levels of industrialization, and most counties being left behind. The shapes of the distributions become much more visible and easier to understand in the next section.

\section{Distributions}

This section reports on the shapes of the distributions for the four variables. As described before, for all four variables we find distributions with positive skewness and kurtosis, showing a clear polarization of the Romanian economy around a few growth poles (outliers) and a large number of under-developed counties.

Figures 1 to 4 visually confirm our findings from the previous section for the four variables of interest. Indeed, there is a large agglomeration of observations on the left side of each distribution, showing most counties to suffer of under-development in: number of firms (Figure 1), number of employees (Figure 2), salary (Figure 3) and degree of urbanization (Figure 4). At the same time, a few over-developed counties distort the value of the mean since they perform very well. In each distribution we find the city of Bucharest as extreme outlier. It represents the particular case of uniquely high economic development according to all four variables.

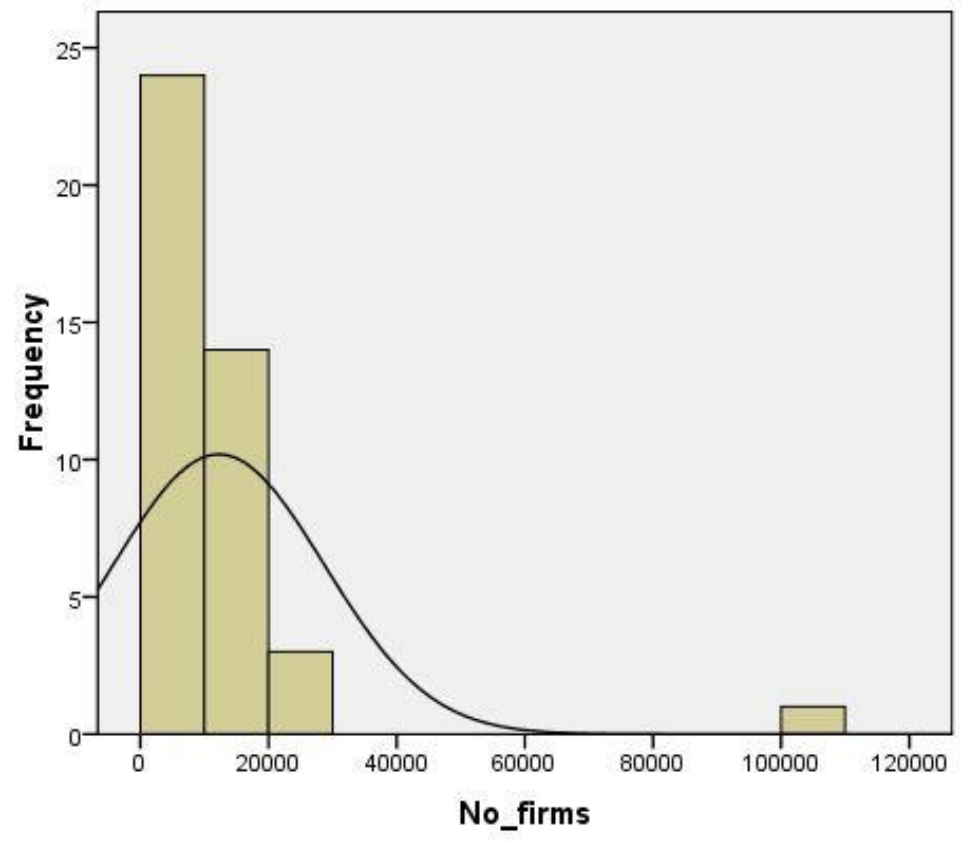

Figure 1. Distribution of number of firms, 2015

Source: Authors' own computations, based on data from the National Institute of Statistics, Romania. 


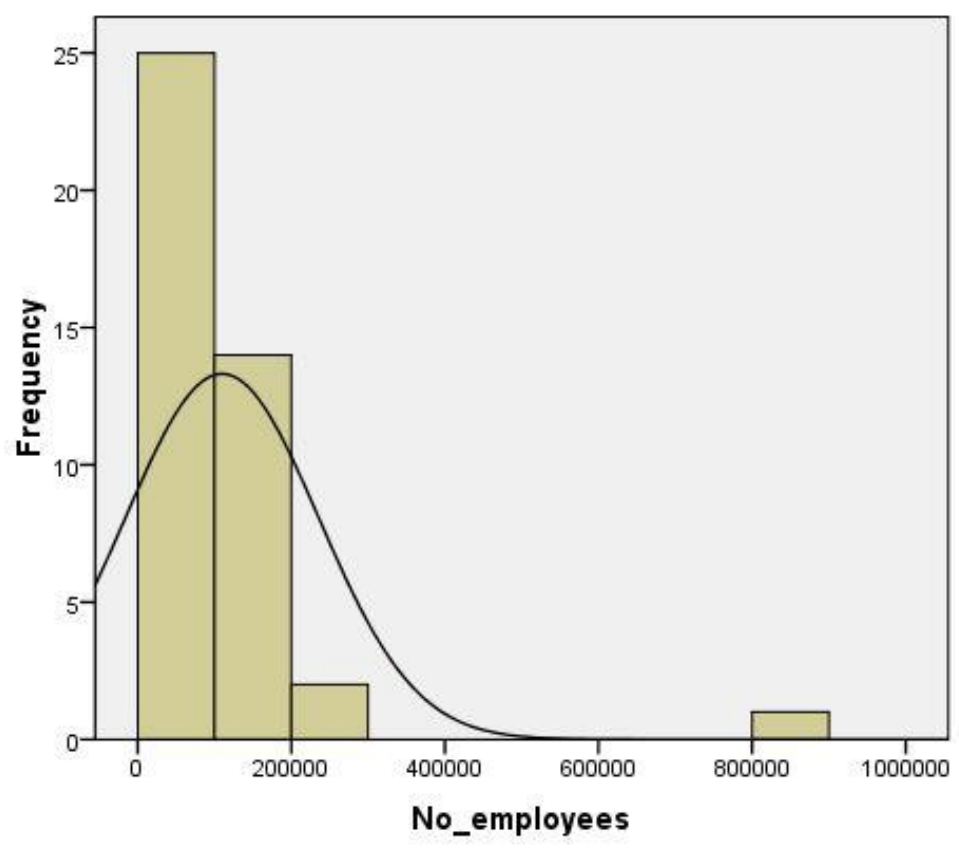

PICBE | 975

Figure 2. Distribution of number of employees, 2015

Source: Authors' own computations, based on data from the National Institute of Statistics, Romania.

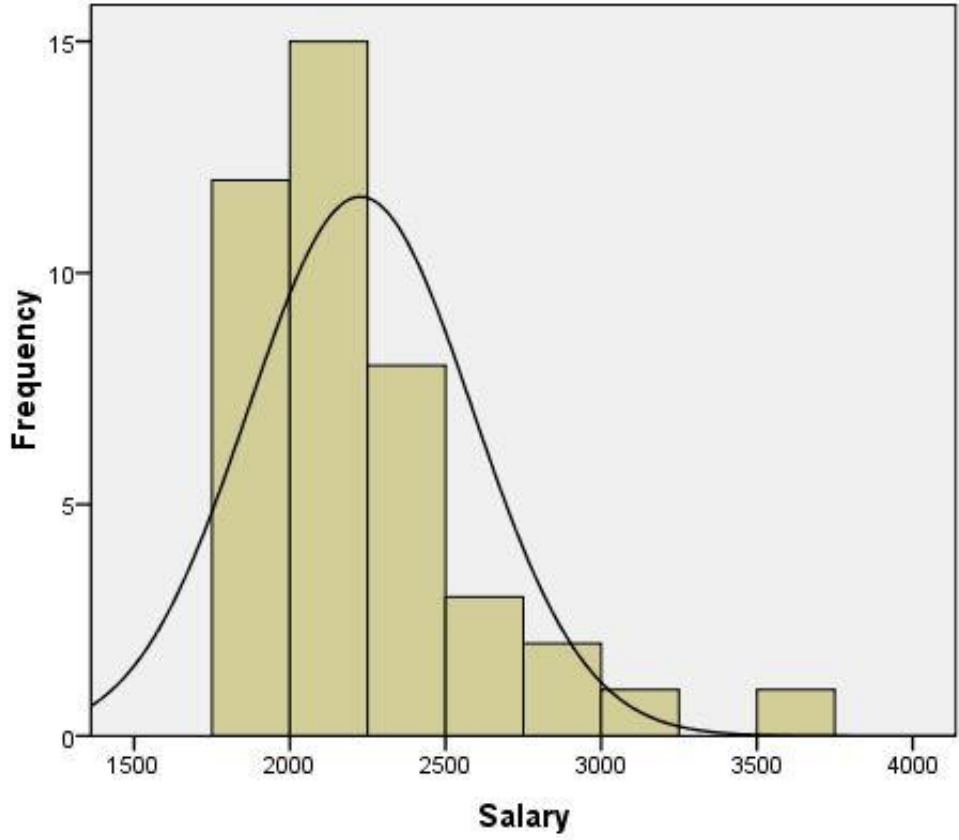

Figure 3. Distribution of salary (RON), 2015

Source: Authors' own computations, based on data from the National Institute of Statistics, Romania. 


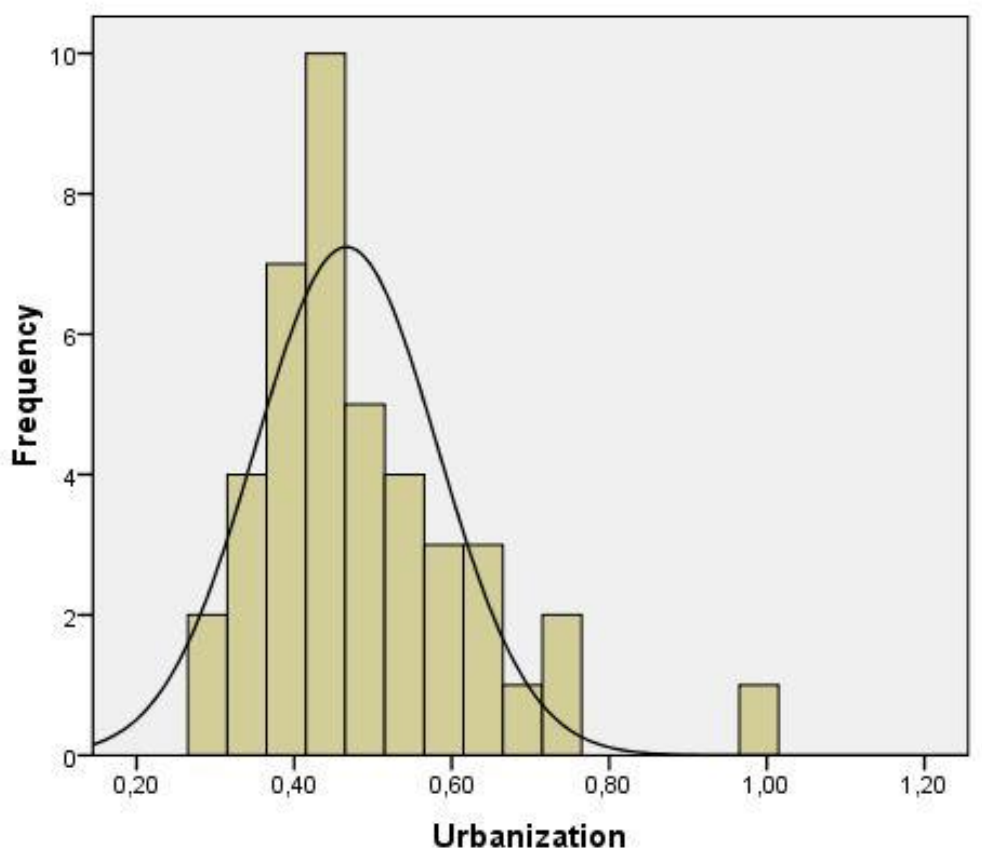

PICBE | 976

Figure 4. Distribution of urbanization, 2015

Source: Authors' own computations, based on data from the National Institute of Statistics, Romania.

It is worth noting that the distributions of number of firms and number of employees are significantly more skewed to the left than salary and degree of urbanization. This indicates that the Romanian economic polarization is more prominent in the number of economic agents (firms, employees) than in their remuneration and urbanization. In Figure 4 , the degree of urbanization is depicted on a value scale from 0 to 1 , where 0 represents a purely rural region and 1 represents a region with 100\% degree of urbanization (in our dataset, only the city of Bucharest achieves this value).

\section{Correlations}

In this section we show results from a correlation analysis between the four variables. They are summarized in Table 2.

Table 2. Pearson correlations between the four variables in 2015

\begin{tabular}{|c|c|c|c|c|}
\hline & & $\begin{array}{l}\text { Number of } \\
\text { Employees }\end{array}$ & Salary & $\begin{array}{l}\text { Degree of } \\
\text { Urbanization }\end{array}$ \\
\hline $\begin{array}{l}\text { Number of } \\
\text { Firms }\end{array}$ & $\begin{array}{l}\text { Pearson correlation } \\
\text { Significance (2-tailed) }\end{array}$ & $\begin{array}{l}0.994^{* *} \\
0.000\end{array}$ & $\begin{array}{l}0.789^{* *} \\
0.000\end{array}$ & $\begin{array}{l}0.700^{* *} \\
0.000\end{array}$ \\
\hline $\begin{array}{l}\text { Number of } \\
\text { Employees }\end{array}$ & $\begin{array}{l}\text { Pearson correlation } \\
\text { Significance (2-tailed) }\end{array}$ & & $\begin{array}{l}0.781^{* *} \\
0.000\end{array}$ & $\begin{array}{l}0.727^{* *} \\
0.000\end{array}$ \\
\hline Salary & $\begin{array}{l}\text { Pearson correlation } \\
\text { Significance (2-tailed) }\end{array}$ & & & $\begin{array}{l}0.599 * * \\
0.000\end{array}$ \\
\hline
\end{tabular}

Source: Authors' own computations, based on data from the National Institute of Statistics, Romania.

In Table 2 we can notice a very high relationship between the number of firms and the number of employees (99.4\%), which should come as no surprise because firms need labor to sustain their activity. Surprising are though the high degrees of correlation between the other variables as well as their very high significance levels. What we can deduct from these correlations is that the degree of economic development, which is 
stronger in some counties and weaker in others, is reflected in all of the four variables, as they vary together. Interestingly, the Romanian economy seems to be more active in cities and less active in rural areas.

\section{Data Map of Counties}

To explain the variance between counties with respect to the four variables, we designed visual data maps which depict the level of development in each county. Appendix 1 provides the full names of the counties, whose abbreviations are used in the data maps.

Figures 5-8 provide strong support for our thesis: there are a few centers driving up the Romanian economy, and a large number of counties left behind. This is mostly visible in Figures 5 and 6, where the contrast is the starkest. According to these figures, the number of firms as well as that of employees are at a record height in Bucharest, followed at large distance by Cluj, Constanta and Timis. In the next cluster we find the counties of Arges, Dolj, Brasov, Iasi, Ilfov and Prahova. The remaining counties have a weaker level of development. A similar pattern can be observed in Figure 7, which maps levels of salary. However, the distribution is less polarized here, as emphasized before in Figure 3. Furthermore, with respect to salary we find the county of Sibiu to have a good level of development. Finally, Figure 8 shows the degree of urbanization in each county. Here we find a more even picture with a less pronounced between-county variation. Still, many counties are still underrepresented here. Besides, the level of urbanization is a weaker indicator of the level of economic development than the previous three variables. All in all, there is strong quantitative support for our thesis.

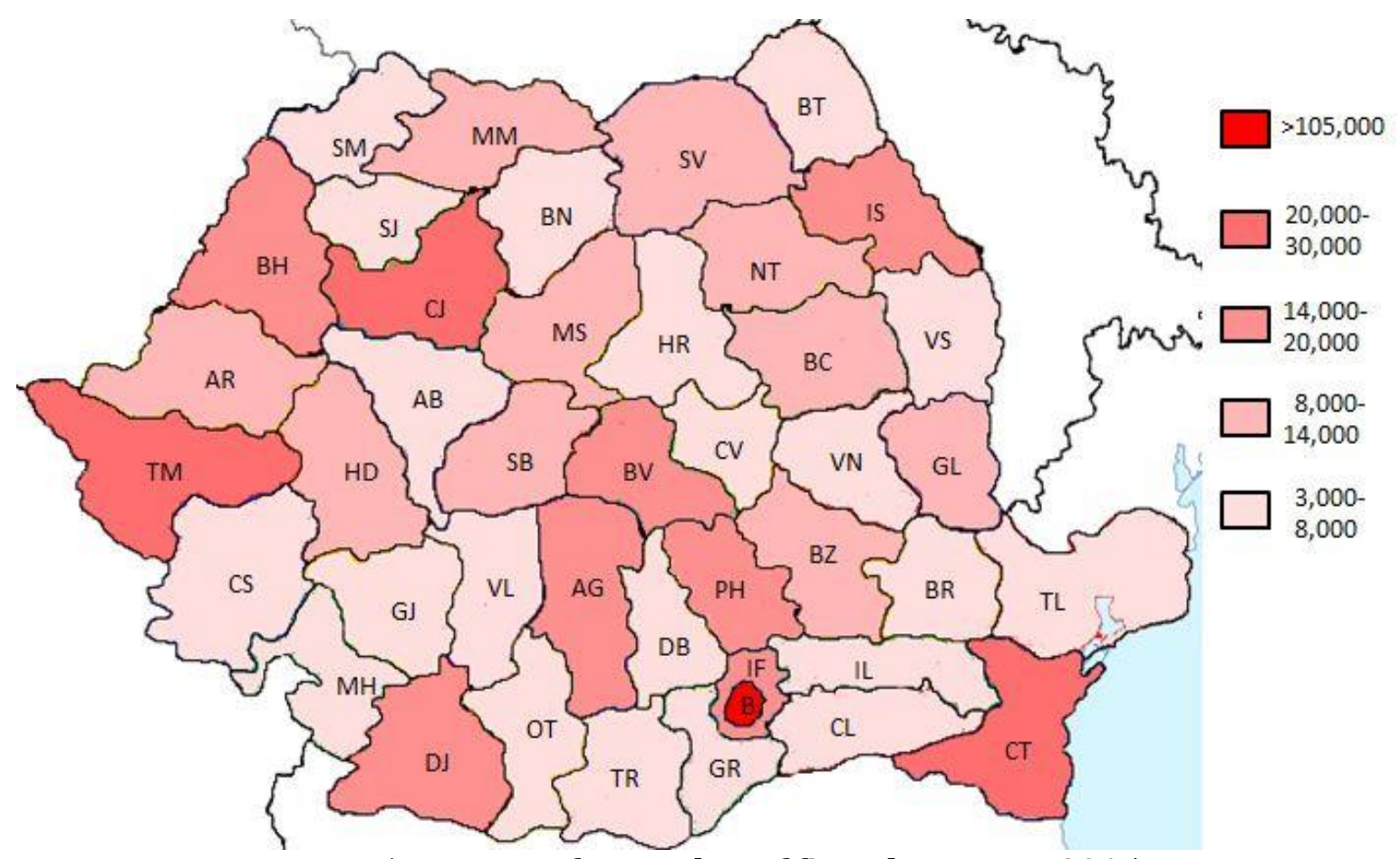

Figure 5. Data map for number of firms by county, 2015

Source: Authors' own graphics, based on data from the National Institute of Statistics, Romania. 


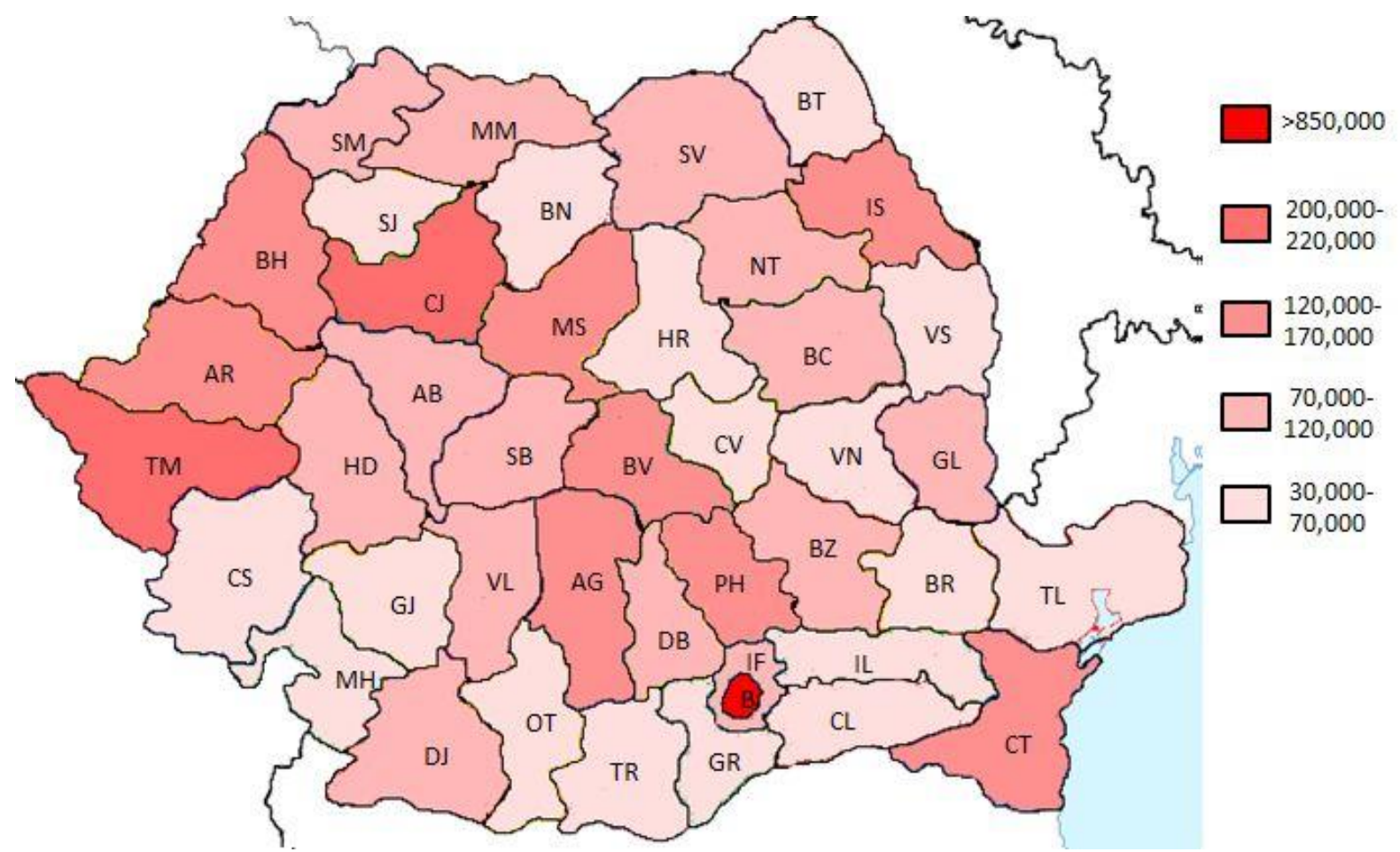

Figure 6. Data map for number of employees by county, 2015

Source: Authors' own graphics, based on data from the National Institute of Statistics, Romania.

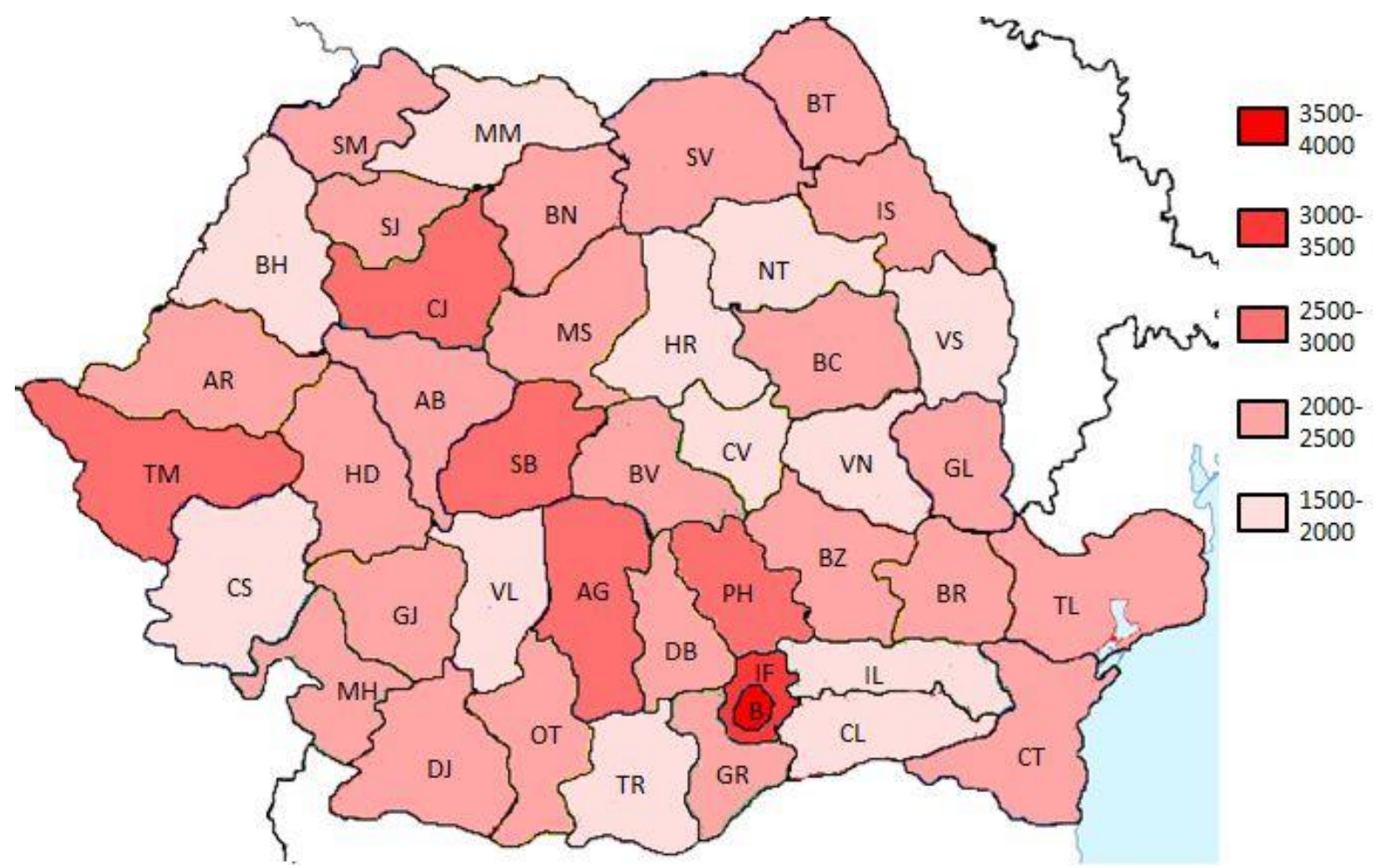

Figure 7. Data map for salary (RON) by county, 2015

Source: Authors' own graphics, based on data from the National Institute of Statistics, Romania. 


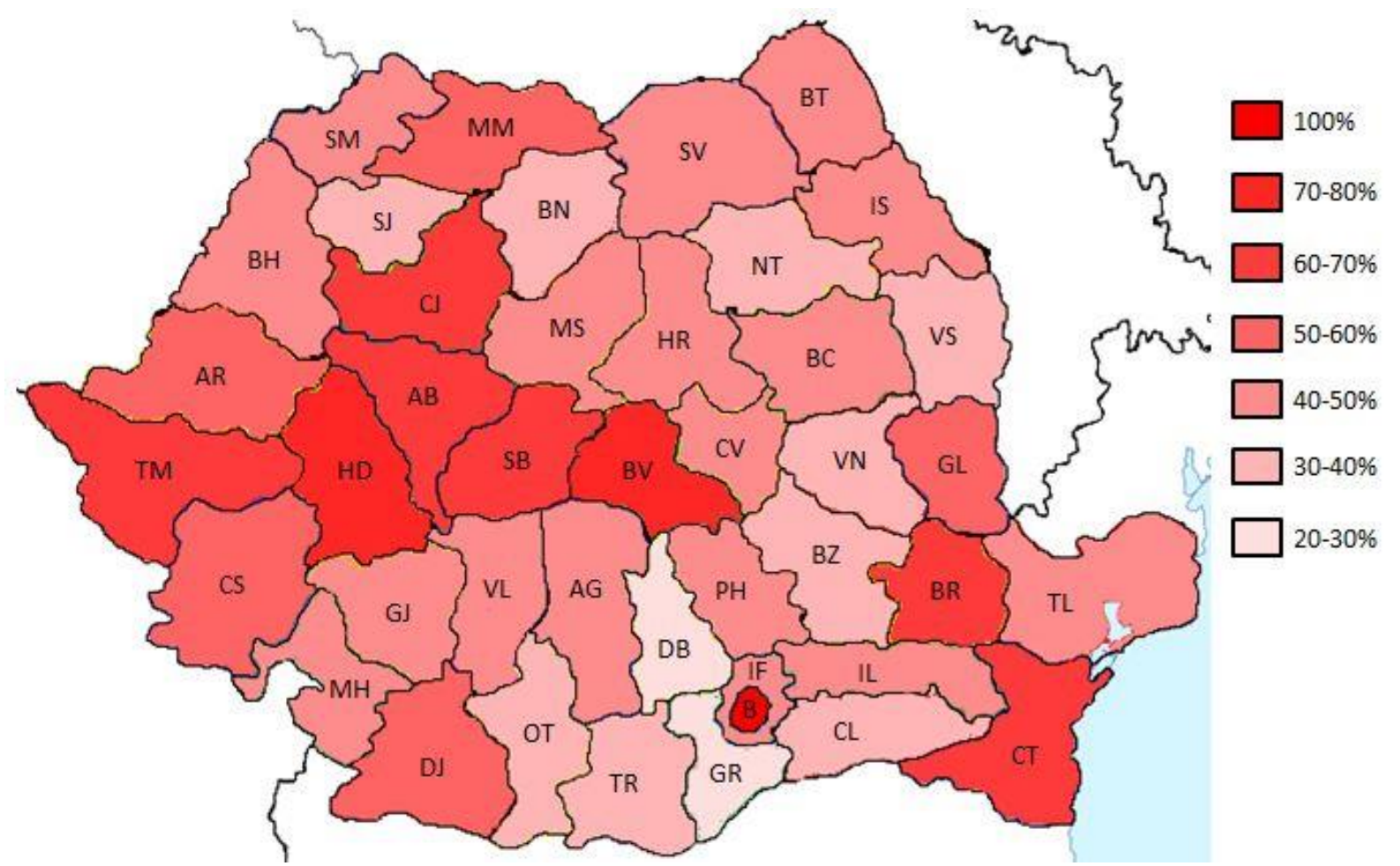

Figure 8. Data map for degree of urbanization by county, 2015

Source: Authors' own graphics, based on data from the National Institute of Statistics, Romania.

\section{Conclusion}

Before starting to list the main findings of our research we are going to proceed by listing the most important limitations of the present paper. This paper should be regarded as an attempt to bring some quantitative evidence supporting the need for resetting the socioeconomic model adopted after the fall of communism by Romania since it supported the creation of high economic discrepancies between regions and in no way it can ensure a future sustainable development. Also, due to its main characteristics which all emphasize the topics of equilibrium and "fair distribution" we consider that the social market economy is an alternative that should be seriously investigated by the Romanian authorities and policy makers.

As an important limitation of the study we need to list the selection of the four variables which might be considered purely subjective but in fact it is constructed using the most important variables used by previous literature when discussing topics related to regional development. Another limitation is represented by the fact that our paper does not investigate the evolution of the four variables over a longer period of time, but we need to mention that this is going to be the approach that we will pursue in a future development of the present study.

The most important idea that our quantitative results have confirmed is that we have a very important polarization, at county level, with a few very strong development poles and with a large number of lagging counties. Another notable aspect is the fact that the degree of urbanization is positively correlated with the other three variables showing 
clearly that the rural area was left behind by the current socio-economic model. Moreover, it points out clearly the areas which have a high propensity of losing population which will be heading towards the more developed urban areas and also towards the more developed west of the EU. The distribution of the salary suggests that on the labor market the supply and demand, at the level of most counties, are severely unbalanced, being therefore a clear break in front of a sustainable development.

Summarizing, we conclude that the present Romanian socio-economic model, which has fuelled the development of the existing socio-economic disparities between the regions of the country, has reached its limits and needs to evolve in a more balanced approach which might be represented by a tailored SME. In our view the development of a new internal model will also help to the increase of the country's role in the broader, rather complicated European context.

\section{References}

Bakan A. B., MacDonald. E. (2002). Critical Political Studies: Debates and Dialogues from the Left. McGill-Queen's Press. pp. 69-70. ISBN 978-0-7735-6956-0.

Buchanan, J. M., 1995/96: Federalism and Individual Sovereignty. In: Cato Journal 15(2-3), 259-268.

Eucken, W. (1932). Staatliche Strukturwandlungen und die Krisis des Kapitalismus, Weltwirtschaftliches Archiv 36, 297-323.

Goldschmidt, N., Rauchenschwandtner, H. (2007). The Philosophy of Social Market Economy: Michel Foucault's Analysis of Ordoliberalism. Universität Freiburg, Freiburger Diskussionspapiere zur Ordnungsökonomik.

Goschin, Z., Constantin, D.L., Roman, M., Ileanu, B. (2008). The current state and the dynamics of regional disparities in Romania, Romanian Journal of Regional Science, 2(2), 80-105.

Hayek, F. A. (1948). [1939]: The Economic Conditions of Interstate Federalism in: Friedrich A. Hayek, Individualism and Economic Order. Chicago: University of Chicago Press, 255-272. (Reprinted from the New Commonwealth Quarterly 5(2), 1939, 131-149).

Müller-Armack, A. (1956). Soziale Marktwirtschaft - Handwörterbuch der Sozialwissenschaften, 9, Göttingen.

Scharpf, F. W. (1988). The Joint-Decision Trap: Lessons from German Federalism and European Integration. In: Public Administration, 66(3), 239-278.

Spicka, M. E., (2007), Selling the Economic Miracle: Economic Reconstruction and Politics in West Germany, 1949-1957, Berghahn Books.

Turner, L. (1998). Fighting for Partnership: Labor and Politics in Unified Germany. Cornell University Press. ISBN 0-8014-8483-9.

Wheeler, S. (2002). Corporations and the Third Way. Hart Publishing. ISBN 978-1-90136263-3. 
Appendix 1

\begin{tabular}{|l|l|l|l|l|l|l|l|}
\hline \multicolumn{1}{|c|}{ County } & Abr. & \multicolumn{1}{c|}{ County } & Abr. & \multicolumn{1}{c|}{ County } & Abr. & \multicolumn{1}{c|}{ County } & Abr. \\
\hline Alba & AB & Cluj & CJ & Harghita & HR & Salaj & SJ \\
\hline Arges & AG & Calarasi & CL & Ilfov & IF & Satu Mare & SM \\
\hline Arad & AR & Caras-Severin & CS & Ialomita & IL & Suceava & SV \\
\hline Bucuresti & B & Constanta & CT & Iasi & IS & Tulcea & TL \\
\hline Bacau & BC & Covasna & CV & Mehedinti & MH & Timis & TM \\
\hline Bihor & BH & Dambovita & DB & Maramures & MM & Teleorman & TR \\
\hline Bistrita-Nasaud & BN & Dolj & DJ & Mures & MS & Valcea & VL \\
\hline Braila & BR & Gorj & GJ & Neamt & NT & Vrancea & VN \\
\hline Botosani & BT & Galati & GL & Olt & OT & Vaslui & VS \\
\hline Brasov & BV & Giurgiu & GR & Prahova & PH & & \\
\hline Buzau & BZ & Hunedoara & HD & Sibiu & SB & & \\
\hline
\end{tabular}

PICBE | 981 